\title{
ANALISA KUALITAS KIMIA DAN MIKROBIOLOGI SUSU KAMBING PERANAKAN ETAWA DENGAN PEMBERIAN PAKAN YANG DITAMBAHKAN TEPUNG KULIT MANGGIS PADA PERSENTASE YANG BERBEDA
}

\author{
Analysis of Chemical Quality and Microbiology with Etawa Crosbreed Goat \\ Milk of the Effect of Additive of the Mangosteen Peel Flour on Different \\ Percentage
Dzarnisa $^{1)}$, Cut Intan Novita ${ }^{1)}$, Yurliasni ${ }^{1)}$, Tri Handayani ${ }^{1)}$, dan Siti Anggraini ${ }^{1)}$ Kopelma Darussalam, Syiah Kuala, Kota Banda Aceh, Aceh, Indonesia 23111 \\ 1) Fakultas Pertanian, Program Studi Peternakan, Universitas Syiah Kuala Jl. Tgk. Hasan Krueng Kalee No.3, \\ Email: dzarnisa@yahoo.com
}

Diterima 19 Februari 2019 ; diterima pasca revisi 28 Maret 2019

Layak diterbitkan 1 April 2019

\begin{abstract}
Dairy goat breeding is an alternative effort to diversify dairy cattle. In increasing milk production, additional ingredients are needed in the feed, one of which is the addition of mangosteen peel flour (Garcinia mangostana L.). The purpose of this study was to determine the chemicals and microbial activity activity of goat milk fed with mangosteen peel flour (MPF). The study was carried out in March - July 2017 at UD Atjeh Livestock, Limpok Village, District of Darussalam, Great Aceh. An experimental study was conducted by using Randomized Block Design (RBD) consisted of 3 groups and 5 treatments, resulted in a total of 15 experimental units. The treatments in this study were consisted of treatment 1 (control, without MPF addition), treatment 2 (with 2.5\% MPF addition), treatment 3 (with 5\% MPF addition), treatment 4 (with $7.5 \%$ MPF addition), and treatment 5 (with $10 \%$ MPF addition). Each treatment was done in triplicate, and the obtained data were analyzed by using ANOVA (Variance Analysis). The measured variables include antioxidant activity, protein content, dry matter content, total microbial amount, $\mathrm{pH}$ measurement, lactic acid and antimicrobial activity of Etawa crossbreed goat milk fed with mangosteen peel flour. The result showed that mangosteen peel flour addition on Etawa Goats feed did not give significant effect on the levels of milk antioxidants, $\mathrm{pH}$, dry matter, total microbial, lactic acid, and antimicrobials. However, the MPF addition affect milk protein content even though the protein content was still in accordance to the SNI standards. The addition of MPF could increase the antioxidants level up to 5\% addition, and increase the milk protein and dry matter content up to $7.5 \%$ addition.
\end{abstract}

Keywords: Etawa crossbreed goat; feed additives; mangosteen peel flour 


\begin{abstract}
ABSTRAK
Upaya peningkatan produksi dan kualitas susu dapat dilakukan melalui perbaikan mutu genetik dan pakan yang baik serta tepat. Pemeliharaan ternak kambing perah merupakan salah satu alternatif upaya diversifikasi ternak perah selain sapi. Dalam meningkatkan produksi susu dibutuhkannya bahan tambahan dalam pakan, salah satunya adalah dengan penambahan tepung kulit manggis (Garcinia mangostana L.). Tujuan dari penelitian ini adalah untuk mengetahui pengaruh pemberian tepung kulit manggis terhadap sifat kimia dan kemampuan tepung kulit manggis dalam menghentikan aktifitas mikroba dalam susu. Penelitian ini dilakuan pada bulan maret - Juli 2017 di UD Atjeh Livestock, Desa Limpok, Kecamatan Darussalam, Kabupaten Aceh Besar. Penelitian ini menggunakan Rancangan Acak Kelompok (RAK) dengan cara mengelompokkan menjadi 3 kelompok dan 5 perlakuan sehingga diperoleh 15 satuan percobaan. Masing-masing perlakuan terdiri dari perlakuan 1 (Ransum kontrol, tanpa penggunaan tepung kulit manggis), perlakuan 2 (Ransum dengan penambahan tepung kulit manggis 2,5\%), perlakuan 3 (Ransum dengan penambahan tepung kulit manggis 5\%), perlakuan 4 (Ransum dengan penambahan tepung kulit manggis 7,5\%), perlakuan 5 (Ransum dengan penambahan tepung kulit manggis 10\%). Data penelitian yang diperoleh dianalisis menggunakan ANOVA (Analysis of Variance) setiap perlakuan terdiri dari tiga ulangan. Parameter yang diamati adalah aktivitas antioksidan, kadar protein, kadar bahan kering susu, perhitungan jumlah total mikroba, pengukuran pH, asam laktat dan uji antimikroba susu kambing Peranakan Etawa yang diberikan tepung kulit manggis. Materi yang digunakan pada penelitian ini yaitu tepung kulit manggis dan kambing perah peranakan Etawa. Penambahan tepung kulit manggis (TKM) pada pakan Kambing Peranakan Etawa tidak memberikan pengaruh terhadap kadar antioksidan, pH susu, bahan kering susu, total mikroba, asam laktat, dan antimikroba susu, akan tetapi berpengaruh nyata terhadap kadar protein susu dan masih sesuai dengan standar SNI. Penambahan tepung kulit manggis dapat meningkatkan kadar antioksidan sampai pada taraf pemberian 5\%, meningkatan kadar protein dan bahan kering susu sampai pada taraf pemberian $7,5 \%$.
\end{abstract}

Kata Kunci: Kambing peranakan etawa; pakan aditif; tepung kulit manggis

\section{PENDAHULUAN}

Kambing Peranakan Etawa (PE) merupakan salah satu ternak yang cukup potensial sebagai penyedia protein hewani (daging dan susu). Kambing PE merupakan bangsa kambing hasil persilangan antara Kambing Kacang dan Kambing Etawa. Kambing PE memiliki sifat antara Kambing Etawa dengan Kambing Kacang. Bobot badan kambing PE sekitar 32 - 37

*Corresponding author:

Dzarnisa

Email: dzarnisa@yahoo.com

Fakultas Pertanian, Program Studi Peternakan, Universitas Syiah Kuala Jl. Tgk. Hasan Krueng Kalee No.3, Kopelma Darussalam, Syiah Kuala, Kota Banda Aceh, Aceh, Indonesia 23111 $\mathrm{kg}$ dan produksi susunya $1-1,5$ liter per hari. Kambing PE berfungsi sebagai ternak penghasil daging dan susu (Setiawan dan Tunis, 2002).

Upaya peningkatan produksi dan kualitas susu dapat ditempuh melalui perbaikan mutu genetik dan melalui pakan yang baik dan tepat. Pemeliharaan ternak kambing perah merupakan salah satu alternatif upaya diversifikasi mengandung ketahanan pangan untuk menjaga kualitas

How to cite:

Dzarnisa., Novita, C. I., Yurliasni., Handayani, T., \& Anggraini, S. (2019). Analisa Kualitas Kimia dan Mikrobiologi Susu Kambing Peranakan Etawa dengan Pemberian Pakan yang Ditambahkan Tepung Kulit Manggis pada Persentase yang Berbeda. Jurnal Ilmu dan Teknologi Hasil Ternak, 14 (1), 30-37 
produksi susu selain dari sapi perah. Pemeliharaan kambing PE relatif lebih murah dan reproduksinya lebih cepat dibandingkan dengan sapi perah. Salah satu upaya untuk meningkatkan produksi susu adalah dengan manajemen ke dalam pakan kambing perah, salah satunya dengan penambahan tepung kulit manggis.

Manggis merupakan tanaman buah yang berasal dari hutan tropis di kawasan Asia Tenggara. Banyaknya produksi buah manggis dapat menimbulkan masalah pada lingkungan terutama yang disebabkan oleh limbah dari kulit manggis setelah isinya dikonsumsi (Permana, 2007). Untuk mengatasi masalah yang ditimbulkan oleh kulit buah manggis ( $G$. Mangostana) tersebut salah satunya adalah memanfaatkan kulit manggis menjadi tepung kulit manggis. Kandungan gizi tepung kulit manggis meliputi vitamin A $8,03 \%$, protein $3,02 \mathrm{~g}$, lemak $6,45 \%$ dan karbohidrat $82,55 \%$. Kulit manggis mengandung senyawa xanthone sebagai antioksidan, antiproliferativ, dan antimikrobial yang tidak ditemui pada buah-buahan lainnya.

Senyawa xanthone meliputi mangostin, mangostenol A, mangostinon A, mangostinon $B$, trapezifolixanthone, tovophyllin $B$, alfa mangostin, beta mangostin, garcinon $B$, mangostanol, flavonoid epicatechin dan gartanin (Qosim, 2007). Senyawa-senyawa tersebut sangat bermanfaat untuk kesehatan manusia, sehingga diharapkan penggunaan tepung kulit manggis dalam pakan memiliki pengaruh yang baik pula terhadap kajian fisiologis dan produksi susu kambing Peranakan Etawa.

\section{MATERI DAN METODE}

Penelitian ini dilakukan di UD. Atjeh Livestock Jln. lingkar kampus Unsyiah, Desa Limpok, Kecamatan Darussalam, Kabupaten Aceh Besar pada Bulan Maret 2017 sampai Mei 2017. Penelitian ini menggunakan metode penelitian Rancangan Acak Kelompok (RAK) yang terdiri dari 5 perlakuan 3 kelompok, ternak dikelompokkan berdasarkan berat badan sehingga diperoleh 15 satuan percobaan. Masing-masing perlakuan terdiri dari pelakuan A (0\% tepung kulit manggis) perlakuan B (2,5\% tepung kulit manggis), perlakuan $\mathrm{C}$ (5\% tepung kulit manggis), dan perlakuan $\mathrm{D} \quad(7,5 \%$ tepung kulit manggis).

Parameter yang diamati yaitu aktivitas antioksidan, kadar protein, kadar bahan kering susu, perhitungan jumlah total mikroba, pengukuran $\mathrm{pH}$, asam laktat dan uji antimikroba susu kambing Peranakan Etawa yang diberikan tepung kulit manggis. Jika terdapat perbedaan antara perlakuan maka akan dilanjutkan dengan Uji Jarak Berganda Duncan.

\section{HASIL DAN PEMBAHASAN}

\section{Nilai Total Mikroba (CFU/ml 10 $\left.{ }^{-5}\right)$}

Rataan total mikroba yang terdapat didalam susu kambing dengan pemberian tepung kulit manggis yang ditambahkan kedalam pakan pada penelitian minggu ke2 dan penelitian minggu ke-4 dapat dilihat pada Tabel 1.

Rataan total mikroba menunjukkan pada susu kambing yang diberikan pakan control memperlihatkan perbedaan jumlah mikroba yang signifikan antara minggu ke2 dengan minggu ke-4, namun setelah pemberian subtitusi tepung kulit manggis P1 $(2,5 \%)$ di minggu ke-2 dan minggu ke-4 terlihat penurunan jumlah total mikroba, begitu juga dengan P2 (5\%) pada minggu ke-2 dan ke-4 menunjukkan penurunan total mikroba yaitu 6,23 dan 6,21, selanjutnya pada perlakuan P3 $(7,5 \%)$ penambahan tepung kulit manggis pada pakan menunjukkan jumlah total mikroba yang terdapat dalam susu pada minggu ke-2 cenderung lebih tinggi, dan terjadi penurunan pada minggu ke-4 sebanyak $1,52 \mathrm{CFU} / \mathrm{ml} 10^{-5}$. 
Tabel 1. Rataan perhitungan total mikroba susu kambing yang diberikan tepung kulit manggis (Garcinia Mangostana L)

\begin{tabular}{lcc}
\hline \multicolumn{1}{c}{ Perlakuan } & $\begin{array}{c}\text { Penelitian Minggu ke-2 } \\
\text { CFU/ml 10 }\end{array}$ & $\begin{array}{c}\text { Penelitian Minggu ke-4 } \\
\text { CFU/ml 10 }\end{array}$ \\
\hline P0 $(0 \%)$ & 2,58 & 6,00 \\
P1 $(2,5 \%)$ & 5,51 & 4,25 \\
P2 (5\%) & 6,23 & 6,21 \\
P3 (7,5\%) & 5 & 3,48 \\
P4 (10\%) & 4,90 & 6,41 \\
\hline
\end{tabular}

Keterangan: $\mathrm{P} 0=$ Pemberian TKM $(0 \%), \mathrm{P} 1=$ Pemberian TKM $(2,5 \%), \mathrm{P} 2=$ Pemberian TKM $(5 \%), \mathrm{P} 3=$ Pemberian TKM $(7,5 \%), \mathrm{P} 4=$ Pemberian TKM $(10 \%)$. Nilai rataan pada total mikroba susu pada minggu ke-2 dan ke-4 pada kelompok menunjukan tidak berpengaruh nyata $(\mathrm{P}>0,05)$.

Sebaliknya penambahan $10 \%$ tepung kulit manggis pada pakan tidak berpengaruh terhadap penurunan jumlah total mikroba, hal ini terlihat bahwa pada perlakuan P4 (10\%) pada minggu ke-2 4,90 meningkat pada minggu ke-4 menjadi 6,41 . Menurut pernyataan (Ngamsaeng and Wanapat, 2004) bahwa pemberian tepung kulit manggis yang terlalu tinggi menyebabkan konsumsi pakan menurun akibat rasa pahit dan bau yang khas, sehingga hal ini mempengaruhi produksi.

Keadaan ini diakibatkan oleh tidak efektifnya pemberian tepung kulit manggis yang terlalu tinggi, hal ini sesuai dengan penelitian (Tambunan, 2007) yang menyatakan bahwa kandungan kulit buah manggis berupa saponin, tanin,dan polifenol mampu menghambat pertumbuhan mikroba. Akan tetapi dalam penelitian ini jumlah total mikroba masih sesuai dengan (SNI, 2000) yaitu jumlah bakteri susu segar maksimal $1 \times 10^{6} \mathrm{cfu} / \mathrm{ml}$. Ditambahkan dengan Rianda (2016) jumlah total mikroba yang terendah terdapat pada perlakuan (5\%) $1,39 \quad \mathrm{CFU} / \mathrm{ml}$ dan $(7,5 \%) 1,18 \mathrm{CFU} / \mathrm{ml}$.

\section{Nilai pH susu Kambing}

Rataan $\mathrm{pH}$ yang terdapat didalam susu kambing dengan pemberian tepung kulit manggis yang ditambahkan kedalam pakan kambing Peranakan Etawa pada minggu ke-2 dan minggu ke-4 dapat dilihat pada Tabel 2 berikut. Pada penelitian ini pemberian tepung kulit manggis tidak mempengaruhi kondisi $\mathrm{pH}$ susu. $\mathrm{pH}$ susu antara 6,63 - 6,87 dan hal ini menunjukkan pengaruh perlakuan yang baik pada susu, karena susu yang baik itu mempunyai $\mathrm{pH}$ sekitar 6,3-6,8.

Tabel 2. Rataan $\mathrm{pH}$ susu kambing yang ditambahkan tepung kulit manggis (Garcinia Mangostana L) dalam pakan kambing Peranakan Etawa (PE)

\begin{tabular}{lcc}
\hline \multicolumn{1}{c}{ Perlakuan } & Penelitian Minggu Ke-2 & Penelitian Minggu Ke-4 \\
\hline P0 $(0 \%)$ & 6,76 & 6,64 \\
P1 $(2,5 \%)$ & 6,86 & 6,80 \\
P2 $(5 \%)$ & 6,87 & 6,81 \\
P3 $(7,5 \%)$ & 6,83 & 6,85 \\
P4 $(10 \%)$ & 6,63 & 6,63 \\
\hline
\end{tabular}

Keterangan: $\mathrm{P} 0=$ Pemberian TKM $(0 \%), \mathrm{P} 1=$ Pemberian TKM $(2,5 \%), \mathrm{P} 2=$ Pemberian TKM (5\%), P3 = Pemberian TKM (7,5\%), P4 = Pemberian TKM (10\%). Nilai rataan pada $\mathrm{pH}$ susu pada minggu ke-2 dan ke-4 pada kelompok menunjukan tidak berpengaruh nyata $(\mathrm{P}>0,05)$. 
Tabel 3. Rataan kadar Asam Laktat pada susu akibat pemberian tepung kulit manggis pada pakan Kambing Peranakan Etawa.

\begin{tabular}{lcc}
\hline \multicolumn{1}{c}{ Perlakuan } & Penelitian Minggu & Penelitian Minggu \\
& Ke-2 & Ke-4 \\
\hline P0 $(0 \%)$ & 0,27 & 0,22 \\
P1 $(2,5 \%)$ & 0,24 & 0,18 \\
P2 $(5 \%)$ & 0,23 & 0,19 \\
P3 $(7,5 \%)$ & 0,27 & 0,34 \\
P4 $(10 \%)$ & 0,29 & 0,24 \\
\hline
\end{tabular}

Keterangan: $\mathrm{P} 0=$ Pemberian TKM $(0 \%), \mathrm{P} 1=$ Pemberian TKM $(2,5 \%), \mathrm{P} 2=$ Pemberian TKM $(5 \%), \mathrm{P} 3=$ Pemberian TKM $(7,5 \%), \mathrm{P} 4=$ Pemberian TKM $(10 \%)$. Nilai rataan pada asam laktat susu pada minggu ke-2 dan ke-4 pada kelompok menunjukan tidak berpengaruh nyata $(\mathrm{P}>0,05)$.

\section{Nilai Asam Laktat Susu Kambing}

Susu segar yang baik tidak mengandung asam laktat, dan asiditas susu segar adalah karena komponen susu tertentu, beberapa diantaranya memberikan reaksi asam dan beberapa lainnya bergabung dengan alkali. Asiditas susu segar disebabkan oleh buffer seperti fosfat susu, protein terutama kasein dan albumin, karbondioksida, sitrat dan sejumlah konstituen minor lain. Bufer lain dalam susu adalah hasil aktivitas bakteri, yaitu asam laktat dan anion-anion organik lain.

Asam dalam susu biasanya disebabkan oleh aktivitas bakteri-bakteri pembentuk asam yang mengakibatkan gula susu diubah menjadi asam laktat (Suardana dan Swacita, 2009). Pemberian tepung kulit manggis pada perlakuan dan kelompok di minggu ke-2 dan minggu ke-4 tidak mempengaruhi kadar asam laktat susu yang dihasilkan. Akan tetapi pemberian tepung kulit manggis mulai 7,5\% menunjukkan kadar asam laktat diatas normal hal ini diakibatkan oleh sedikitnya konsumsi pakan. Berdasarkan grafik diatas dapat terlihat bahwa pemberian tepung kulit manggis pada perlakuan $2 \quad(5 \%)$ menunjukkan asam laktat yang normal.

\section{Antimikroba}

Pengujian antimikroba atau daya hambat dilakukan dengan mengukur diameter zona hambat yang terlihat pada cawan petri yang ditanam dengan bakteri
Escherichia coli sebanyak $10^{3} \mathrm{CFU} / \mathrm{ml}$ dan sudah diinkubasi selama 24 jam pada suhu $37^{\circ} \mathrm{C}$. Data yang diperoleh menunjukkan bahwa susu kambing yang diberikan setiap level tepung kulit manggis tidak memiliki kemampuan antibakter.

Ada beberapa factor yang mempengaruhi aktivitas daya hambat anti bakteri antara lain inoculum, suhu inkubasi, pemasangan cakram waktu ingkubasi dan anti biotik. Antibakteri (berupa senyawa yang digunakan untuk mengendalikan bakteri yang bersifat merugikan) pada pengujian sampel perlakuan tidak ditemukan, ini disebabkan oleh tidak adanya aktivitas anti bakteri untuk menghambat bakteri pathogen. Pada gambar dibawah ini dapat dilihat bahwa tidak terbentuknya zona hambat yang ditimbulkan sampel perlakuan.

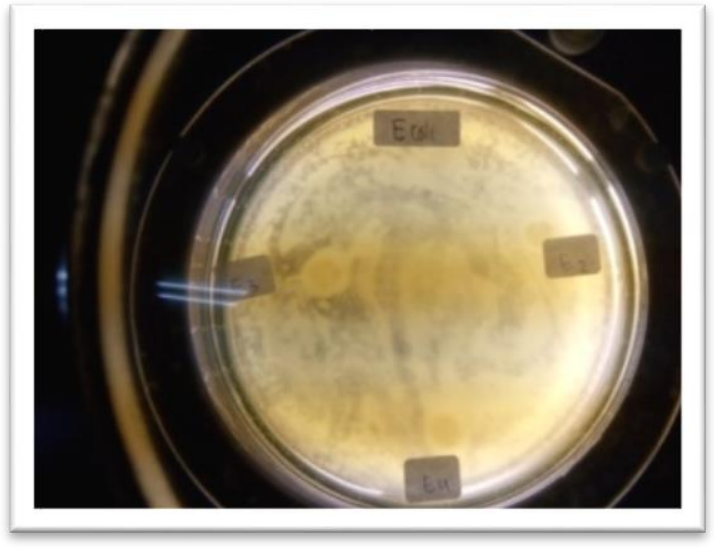

Gambar 1. Uji antimikroba 


\section{Kadar Antioksidan}

Kadar antioksidan dalam susu kambing diuji dengan menggunakan metode DPPH (2,2-difenil-pikrilhidrazil). Kadar rataan antioksidan dalam susu kambing Peranakan Etawa dapat dilihat pada Tabel 4 berikut.

Peningkatan kadar antioksidan akibat penambahan tepung kulit manggis sampai pada taraf $5 \%$ yaitu sebesar $34,63 \%$, dan kemudian menurun pada perlakuan $7,5 \%$ dan $10 \%$, walaupun demikian kadar antioksidan tersebut masih diatas kadar antioksidan pada perlakuan kontrol, sehingga dapat dikatakan bahwa penambahan tepung kulit manggis dapat meningkatkan kadar antioksidan dalam susu kambing Peranakan Etawa, walaupun secara analisa statistik tidak menunjukkan adanya perbedaan.

Tabel 4. Rataan kadar Antioksidan pada susu akibat pemberian tepung kulit manggis pada pakan Kambing Peranakan Etawa.

\begin{tabular}{|c|c|c|c|c|c|c|c|}
\hline \multirow{2}{*}{ Kelompok- } & \multicolumn{5}{|c|}{ Penambahan Tepung Kulit Manggis } & \multirow{2}{*}{ Total } & \multirow{2}{*}{ Rataan } \\
\hline & $\mathrm{P} 0(0 \%)$ & $\mathrm{P} 1(2,5 \%)$ & $\mathrm{P} 2(5 \%)$ & P3 $(7,5 \%)$ & P4 (10\%) & & \\
\hline $1(32-36)$ & 10,38 & 9,46 & 9,22 & 11,33 & 7 & 47,39 & $9,48 \pm 0,27^{\mathrm{a}}$ \\
\hline $2(37-41)$ & 9,6 & 12,35 & 17,69 & 13,81 & 14,63 & 68,08 & $13,62+0,50^{\mathrm{b}}$ \\
\hline $3(42-46)$ & 9,99 & 10,9 & 13,45 & 12,57 & 10,2 & 57,11 & $11,42 \pm 0,25^{\mathrm{ab}}$ \\
\hline Total & 29,97 & 32,71 & 40,36 & 37,71 & 31,83 & 172,58 & \\
\hline Rataan & $9,99 \pm 0,39$ & $10,90 \pm 1,44$ & $13,45 \pm 4,23$ & $12,57 \pm 1,24$ & $10,61 \pm 3,83$ & & \\
\hline
\end{tabular}

Keterangan: $\mathrm{P} 0=$ Pemberian TKM $(0 \%), \mathrm{P} 1=$ Pemberian TKM $(2,5 \%), \mathrm{P} 2=$ Pemberian TKM $(5 \%)$, P3 = Pemberian TKM (7,5\%), P4 = Pemberian TKM $(10 \%)$.

Tabel 5. Rataan kadar Protein pada susu akibat pemberian tepung kulit manggis pada pakan Kambing Peranakan Etawa.

\begin{tabular}{|c|c|c|c|c|c|c|c|}
\hline \multirow{2}{*}{ Kelompok } & \multicolumn{5}{|c|}{ Penambahan Tepung Kulit Manggis } & \multirow{2}{*}{ Total } & \multirow{2}{*}{ Rataan } \\
\hline & P0 (0\%) & P1 $(2,5 \%)$ & P2 (5\%) & P3 $(7,5 \%)$ & P4 (10\%) & & \\
\hline $1(32-36)$ & 2,73 & 2,93 & 3,51 & 3,51 & 3,12 & 15,8 & $3,16 \pm 0,06^{\mathrm{a}}$ \\
\hline $2(3$ & 3,51 & 3,51 & 3,7 & 3,9 & 3,7 & 18,32 & $03^{\mathrm{c}}$ \\
\hline $3(42-46)$ & 3,12 & 3,22 & 3,6 & 3,7 & 3,51 & 17,15 & $3,43 \pm 0,04^{\mathrm{b}}$ \\
\hline Total & 9,36 & 9,66 & 10,81 & 11,11 & 10,33 & 51,27 & \\
\hline Rataan & $3,12 \pm 0,39^{a}$ & $3,22 \pm 0,29^{\mathrm{a}}$ & $3,60 \pm 0,09$ & $3,70 \pm 0,19^{\circ}$ & $3,44 \pm 0,29^{b}$ & & \\
\hline
\end{tabular}

Keterangan: $\mathrm{P} 0=$ Pemberian TKM $(0 \%), \mathrm{P} 1=$ Pemberian TKM $(2,5 \%), \mathrm{P} 2=$ Pemberian TKM (5\%), P3 = Pemberian TKM (7,5\%), P4 = Pemberian TKM (10\%). Nilai rataan dalam kolom yang sama secara statistik berpengaruh nyata $(\mathrm{P}<0,05)$

\section{Kadar Protein}

Salah satu faktor yang dapat mempengaruhi kualitas susu adalah factor pakan, pakan yang baik akan menghasilkan susu yang berkualitas baik pula. Dalam hal ini pemberian tepung kulit manggis sebagai pakan aditif ditambahkan kedalam konsentrat mampu mempertahankan konsumsi pakan ternak, sehingga ternak cenderung mengkonsumsi semua bahan pakan perlakuan. Kandungan nutrient dalam hijauan belum mencukupi kebutuhan nutrient untuk ternak sehingga diperlukan pemberian konsentrat sebagai pakan penguat sekaligus sebagai faktor pertambahan kadar protein dalam susu. Selain itu peningkatan kadar protein pada susu juga diduga karena tepung kulit manggis yang memiliki kandungan dalam jumlah yang lebih besar dari jumlah kandungan lemak dan karbohidrat. Analisa kadar protein dalam susu kambing Peranakan Etawa dilakukan dengan uji formol menggunakan titrasi $\mathrm{NaOH}$. Data rataan kadar protein dalam susu kambing Peranakan Etawa dapat dilihat pada Tabel 6.

Pemberian tepung kulit manggis sampai pada taraf $10 \%$ dapat meningkatkan kadar protein susu kambing Peranakan 
Etawa, dan kadar protein yang terbaik terdapat pada penambahan TKM sebanyak $7,5 \%$ yaitu $3,70 \%$, kadar protein ini sedikit lebih tinggi dari kadar protein susu kambing, yaitu 3,6\% dan lebih rendah dari hasil penelitian yang dilakukan oleh Zurriyati et al., (2011) yaitu sebesar 4,29\%. Kadar protein untuk susu kambing kelas premium adalah minimum $2,8 \%$ dan maksimum $3,7 \%$.

Tabel 6. Rataan kadar Bahan Kering pada susu akibat pemberian tepung kulit manggis pada pakan Kambing Peranakan Etawa.

\begin{tabular}{|c|c|c|c|c|c|c|c|}
\hline \multirow[b]{2}{*}{ Kelompok } & \multicolumn{5}{|c|}{ Penambahan Tepung Kulit Manggis } & \multirow[b]{2}{*}{ Total } & \multirow[b]{2}{*}{ Rataan } \\
\hline & $\mathrm{P} 0(0 \%)$ & P1 $(2,5 \%)$ & $\mathrm{P} 2(5 \%)$ & $\begin{array}{c}\mathrm{P} 3 \\
(7,5 \%)\end{array}$ & P4 (10\%) & & \\
\hline $1(32-36)$ & 13,96 & 12,96 & 13,04 & 13,6 & 11,69 & 65,24 & $13,04 \pm 0,14$ \\
\hline $2(37-41)$ & 12,98 & 11,14 & 13,48 & 16,33 & 14,1 & 68,03 & 0,31 \\
\hline $3(42-46)$ & 13,47 & 12,04 & 13,26 & 14,96 & 13,71 & 67,44 & $13,48 \pm 0,17$ \\
\hline Total & 40,41 & 36,13 & 39,78 & 44,89 & 39,5 & 200,71 & \\
\hline Rataan & $13,47 \pm 0,49$ & $12,04 \pm 0,90$ & $13,26 \pm 0,22$ & $1,96 \pm 1,36$ & $13,417 \pm 1,29$ & & \\
\hline
\end{tabular}

Keterangan: $\mathrm{P} 0=$ Pemberian TKM $(0 \%), \mathrm{P} 1=$ Pemberian TKM $(2,5 \%), \mathrm{P} 2=$ Pemberian TKM $(5 \%), \mathrm{P} 3=$ Pemberian TKM $(7,5 \%), \mathrm{P} 4=$ Pemberian TKM $(10 \%)$. Nilai rataan dalam kolom yang sama secara statistik tidak berbeda nyata $(\mathrm{P}>0,05)$

Hal ini menunjukkan bahwa kandungan protein yang digunakan dalam pakan perlakuan masih tergolong tinggi yang berarti protein tidak banyak mengalami kerusakan akibat proses pembuatan kulit manggis menjadi tepung sehingga dapat dimanfaatkan menjadi pakan aditif untuk mempertahankan kadar protein susu.

\section{Kadar Bahan Kering}

Kadar bahan kering susu tergantung zat-zat makanan yang dikonsumsi oleh ternak yang kemudian digunakan sebagai precursor dalam pembentukan bahan kering atau padatan didalam susu. Kadar bahan kering pada susu kambing Peranakan Etawa dilakukan dengan metode analisa proksimat. Rataan kadar bahan kering dapat dilihat pada Tabel 6 .

Rataan kadar bahan kering pada penelitian ini berkisar antara 12,04\% $14,96 \%$. Hasil tersebut lebih tinggi dibandingkan dari nilai SNI untuk kadar bahan kering susu kambing yaitu 11,0\%. Akan tetapi, kadar bahan kering susu kambing dari hasil penelitian ini masih dibawah rataan kadar bahan kering susu kambing hasil penelitian Budi (2002) yaitu sekitar $14,70-15,72 \%$.

\section{KESIMPULAN}

Perlakuan penambahan tepung kulit manggis tidak memberi pengaruh terhadap kadar antioksidan, total mikroba, kadar asam laktat, kadar $\mathrm{pH}$, dan bahan kering susu kambing Peranakan Etawa, akan tetapi mempengaruhi kadar protein susu kambing Peranakan Etawa. Penambahan tepung kulit manggis juga dapat meningkatkan kadar antioksidan sampai pada taraf pemberian $5 \%$, dan dapat meningkatkan kadar protein dan bahan kering susu sampai pada taraf pemberian $7,5 \%$.

\section{UCAPAN TERIMAKASIH}

Penulis menyampaikan terima kasih kepada: Kemenristek Dikti yang telah mendanai riset ini melalui Skim Penelitian Unggulan Perguruan Tinggi, Bapak Rektor Unsyiah, Bapak Ketua LPPM Unsyiah beserta staf, Bapak Dekan Fakultas Pertanian Unsyiah, Ibu Kaprodi Peternakan Unsyiah, Tim Peneliti, Mitra Penelitian UD. Aceh Livestock Farm, dan semua pihak yang telah membantu baik di lapangan maupun di laboratorium mulai dari pnelitian sampai penulisan makalah ini. 


\section{DAFTAR PUSTAKA}

Budi, U. (2002). Pengaruh Interval Pemerahan terhadap Produksi Susu dan Aktivitas Seksual Setelah Beranak pada Kambing Peranakan Etawa (Tesis). Bogor: Program Pascasarjana Institut Pertanian Bogor.

Ngamsaeng, A., Wanapat, M., \& Khampa, S. (2006). Effects of mangosteen peel (garcinia mangostana) supplementation on rumen ecology, microbial protein synthesis, digestibility and voluntary feed intake in cattle. Pakistan Journal of Nutrition, 5(5), 445-452. https://doi.org/10.3923/pjn.2006.445.452

Permana, A. W. (2007). Kulit Buah Manggis dapat Menjadi Minuman Instan Kaya Antioksidan. Pustaka Litbang.

Qosim, W. A. (2007). Kulit Buah Manggis Sebagai Antioksidan. Plantus.
Setiawan, \& Tunis. (2002). Beternak Kambing Peranakan Etawa. Bandung: Penebar Swadaya

Suardana, I. W., \& Swacita, I. B. (2009). Higien Makanan. Kajian Teori dan Prinsip Dasar.

Tambunan, I. R. (2007). Pengaruh Pemberian tepung Karkas Koran Pada Periode GrowerTerhadap Presentase Karkas, Lemak Abdominal, Organ Dalam dan Saluran Pencernaan Ayam Broiler (Skripsi). Fakultas Peternakan IPB Bogor: Udayana Universitas Prees.

Zurriyati, Y., Noor, R., \& Maheswari, R. R. (2011). Analisis molekuler genotipe kappa kasein ( $\kappa$-kasein) dan komposisi susu kambing Peranakan Etawa, Saanen dan Persilangannya. Jurnal Ilmu Ternak Dan Veteriner, 16(1), 61-70. 